Stanivuković, S., Pašalić, B., Jakovljević, J., Ilić, P. (2021): Influence of storage on pomological and sensory characteristics of hazelnut fruit. Agriculture and Forestry, 67 (1): 205-213

DOI: 10.17707/AgricultForest.67.1.17

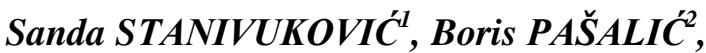 \\ Jovana JAKOVLJEVIĆ ${ }^{2}$, Predrag ILIĆ
}

\title{
INFLUENCE OF STORAGE ON POMOLOGICAL AND SENSORY CHARACTERISTICS OF HAZELNUT FRUIT
}

\section{SUMMARY}

The research aims to study the changes in pomological and sensory characteristics of hazelnuts fruits before and after NA cold storage for five months. The paper analyzes fruits of hazelnut cultivars grown in agroecological conditions of north-western Bosnia and Herzegovina, in the area of municipality Kostajnica. The fruits were collected in the period of full maturity, in the 2020 year, and the following cultivars were analyzed: Istrian Long, Istrian Round, Romische Zellernuss and Cosford. The first analysis of fruits was performed after harvest, and the second analysis was executed after the storage of fruits in the shell. Fruit characteristics, studied on both period, were fruit weight, kernel weight, fruit length, fruit width, fruit thickness, kernel length, kernel width, kernel thickness, shell thickness, fruit shape, texture, color, taste, kernel bitterness, kernel sweetness, hardness, crunchiness, presence of double fruits, blank nuts, fruit roundness index and kernel percentage.

The results of the research show that there are significant differences in the values of the examined parameters before and after storage of fruit hazelnut. The biggest changes are recorded precisely on the shrinkage in the storage process and changes in the taste of stored hazelnuts. These results show the need to more investigate storage systems and optimal storage conditions for each variety.

Keywords: Corylus avellana L., fruit quality, drying, NA storage

\section{INTRODUCTION}

Hazelnut, as a nut fruit species, has a significant demand on the world market, primarily in the confectionery industry, and recently as a raw material for the production of cold-pressed oils and for the needs of the cosmetics industry. The growth in demand for hazelnuts in recent years has led to their deficit in the

\footnotetext{
${ }^{1}$ Sanda Stanivuković (corresponding author: sanda.stanivukovic@igr.unibl.org), Predrag Ilić, University of Banja Luka, Genetic Resources Institute, Bulevar vojvode Petra Bojovića 1A, 78000 Banja Luka, BOSNIA AND HERZEGOVINA.

${ }^{2}$ Boris Pašalić, Jovana Jakovljević, University of Banja Luka, Faculty of Agriculture, Bulevar vojvode Petra Bojovića 1A, 78000 Banja Luka, BOSNIA AND HERZEGOVINA.

Notes: The authors declare that they have no conflicts of interest. Authorship Form signed online. 
world market and a significant increase in price, which has further influenced the emergence of expansion in terms of raising new hazelnut plantations around the world. A drastic increase in the area under hazel is also recorded in the Western Balkans. So, the current areas under hazel in Serbia are 3,964 ha (Statistical office of the Republic of Serbia, 2017), in Croatia 5,530 ha (Croatian Bureau of statistics, 2019), while for Bosnia and Herzegovina (B\&H) there are no data related to areas under hazel. Zavišić et al. (2020) state that during 2019, only in Republic of Srpska were produced 168,990 seedlings of hazelnut, which is 15 times more than in 2016, and also a large amount of planting material is imported from other countries.

Old and introduced cultivars are grown in newly planted orchards of hazelnut. Hazelnuts are grown in B\&H exhibit different production characteristics that are closely related to agroecological conditions. Cmelik and Mališević (1996) state that in the hazelnut orchard planted on pseudogley soil in the Posavina area, there is a disturbance of the growth and yield of plants and the presence of fruits with poor production characteristics, especially in dry years. On the other hand, Ilić et al. (2017) state that hazelnut fruits in 13 cultivated varieties at several different locations from the Banja Luka region showed good morphometric and qualitative characteristics, which was confirmed by other researchers from the Western Balkan (Mitrović et al., 2009; Solar and Stampar, 2011; Skender et al., 2019).

The process of hazelnut production is extremely important for preserving the quality of the fruit and its aroma and taste until it is placed on the market, either for consumer use or as a raw material in the confectionery industry. Untimely harvesting, cleaning, drying and storage can significantly affect the loss of fruit quality of this kernel species. Drying before storing fruits is especially important because if it is not performed properly due to changes in temperature and light, lipid molecules are released that form free fatty acids, which further leads to changes and oxidation of oil (Turan, 2018).

In recent years, hazelnut producers in Bosnia and Herzegovina have marketed their hazelnuts mainly in local markets and pastry shops. With the increase in production, there has been a certain saturation of the market because there are no large domestic buyers of hazelnuts in our area, while foreign buyers have requirements that most producers do not meet, primarily due to the larger size of the fruit. In such conditions, there is a need to store fruits until they find their way on the market. Thus, growers are forced to store hazelnuts in improvised ways, ie in storage that do not fully meet the required norms. Controlled atmospheric conditions have a positive impact on the quality and nutritional value of hazelnuts (Markuszewski and Kopytowski, 2015). The same authors concluded that the dry matter content of hazelnuts doubles and the fruit weight decreases after three months of storage in a NA chamber compared to harvest. In the warehouse, there are changes in the sensory properties of the fruit, which is confirmed by De Santis et al. (2009), and especially emphasize the change in taste and crunchiness of the fruit. Miljkovic (2018) states that properly 
stored hazelnuts can be stored for up to 40 months without loss of weight and quality.

The aim of this research is to study the quality of hazelnuts at harvest and after storage in order for producers to give recommendations on the possibility of storage period without declining their quality.

\section{MATERIAL AND METHODS}

The research was done during 2020 and 2021 in the experimental orchard and cold storage "Strigo" in the area of municipality of Kostajnica on four cultivars of hazelnuts - Istrian Long, Istrian Round, Romische Zellernuss and Cosford. The fruits are harvested in September in the optimal period for harvesting. For each cultivar, 100 fruits were sampled, and they are divided into two groups. On the first group of fruits, analyzes were performed immediately after harvest (30 fruits for pomological analyzes and 20 fruits for sensory analysis of which 10 fruits of the samples was subjected to roasting for 20 minutes at temperature $115^{\circ} \mathrm{C}$ (IPBGR, 2008), (Gorenje, EC5111SG, Slovenia). The second group of fruits was placed in storage at a temperature of $7-8{ }^{\circ} \mathrm{C}$ and at a relative humidity of $70 \%$. The fruits were stored for five months after which the analyzes were repeated. Before storage, the fruits were dried in a dryer for three days at temperature $25-30^{\circ} \mathrm{C}$.

From pomological characteristics of the fruit were monitored: length, width and thickness of fruit, length, width and thickness of kernel, shell thickness by movable scale (Unior, No 270, Slovenia, measuring range 0-150 mm), fruit and kernel weight by analytical balance (KERN \& Sohn Gmbh, Germany, measuring range $0-600 \pm 0.01 \mathrm{~g}$ ), kernel percentage was calculated using the formula: kernel percentage $(\%)=($ kernel weight/fruit weight $) \times 100)$. The index of fruit roundness was calculated according to the formula: fruit roundness index = (thickness + width $) /(2 \times$ length $)$. Thus, were observed the presence of blank fruits and fruits with two kernels. Sensory analysis of fruits was performed using Bioversity Descriptors for hazelnut (IPBGR, 2008), and the monitored characteristics are fruit shape, texture, color, taste, kernel bitterness, kernel sweetness, hardness, and crunchiness of the fruit. The evaluation of sensory characteristics was performed by respondents of different ages and genders. Statistical data processing was performed on the basis of descriptive analysis with appropriate data for all measured properties. Examination and comparison of the observed properties were performed by calculating the mean values and standard error.

\section{RESULTS AND DISCUSSION}

The results of the research of the observed hazelnut cultivars from the Kostajnica area showed different values of the analyzed parameters before and after fruit storage.

The average values of pomological characteristics of the fruit in the examined hazelnut cultivars at harvest period are presented in Table 1. 
Table 1. Average values of pomological characteristics of fruits of examined hazelnut cultivars at harvest period

\begin{tabular}{|l|c|c|c|c|}
\hline \multirow{2}{*}{\multicolumn{1}{|c|}{ Harvest period }} & \multicolumn{4}{c|}{ Cultivars } \\
\cline { 2 - 5 } & $\begin{array}{c}\text { Romische } \\
\text { Zellernuss }\end{array}$ & $\begin{array}{c}\text { Istrian } \\
\text { Long }\end{array}$ & $\begin{array}{c}\text { Istrian } \\
\text { Round }\end{array}$ & Cosford \\
\hline Measurements & Mean SE & Mean SE & Mean SE & Mean SE \\
\hline Nut weight (g) & $3.10 \pm 0.10$ & $4.04 \pm 0.11$ & $2.54 \pm 0.08$ & $2.18 \pm 0.04$ \\
\hline Kernel weight (g) & $1.48 \pm 0.04$ & $1.82 \pm 0.04$ & $1.21 \pm 0.03$ & $1.10 \pm 0.02$ \\
\hline Nut lenght (mm) & $19.28 \pm 0.19$ & $25.69 \pm 0.20$ & $19.29 \pm 0.18$ & $23.72 \pm 0.15$ \\
\hline Nut width (mm) & $22.15 \pm 0.33$ & $20.70 \pm 0.16$ & $18.78 \pm 0.17$ & $15.58 \pm 0.20$ \\
\hline Nut thickness (mm) & $19.16 \pm 0.19$ & $17.74 \pm 0.13$ & $16.76 \pm 0.16$ & $13.68 \pm 0.14$ \\
\hline Kernel lenght (mm) & $13.89 \pm 0.25$ & $20.10 \pm 0.20$ & $14.87 \pm 0.20$ & $19.21 \pm 0.12$ \\
\hline Kernel width (mm) & $16.88 \pm 0.27$ & $14.63 \pm 0.27$ & $14.71 \pm 0.22$ & $11.35 \pm 0.12$ \\
\hline Kernel thickness (mm) & $14.86 \pm 0.35$ & $12.46 \pm 0.22$ & $12.75 \pm 0.23$ & $10.32 \pm 0.15$ \\
\hline Shell thickness (mm) & $1.39 \pm 0.04$ & $1.97 \pm 0.34$ & $1.56 \pm 0.03$ & $1.23 \pm 0.02$ \\
\hline Presence od dual fruits & None & Presence & Presence & None \\
\hline Blank nuts $(\%)$ & 13.33 & 6.66 & 6.66 & 3.33 \\
\hline Nut shape index & 1.07 & 0.74 & 0.92 & 0.61 \\
\hline Kernel percentage (\%) & 45.87 & 45.73 & 46.66 & 50.45 \\
\hline
\end{tabular}

Prior to fruits storage, the highest average weight of fruits and kernels had Istrian Long (4.04 and $1.82 \mathrm{~g}$ ), and smallest Cosford (2.18 and $1.10 \mathrm{~g}$ ). In relation to the research conducted by Ilić et al. (2017) were observed lower nut weight and higher kernel weight in Istrian Long, as well as higher nut and kernel weight in Romische Zellernuss. According to measurements performed by Solar and Štampar (2011), a lower nut weight was recorded in Istrian Long, and a higher one in Romische Zellernuss. Skender et al. (2019) record a significantly lower nuts and kernel weight for Istrian Long in the Bihać area $(2.41 \mathrm{~g})$ and approximately the same Romische Zellernuss $(3.04 \mathrm{~g})$. The highest nut length was recorded in Istrian Long $(25.69 \mathrm{~mm})$, and the smallest in Romische Zellernuss $(19.28 \mathrm{~mm})$. The largest width and thickness of nuts was recorded in Romische Zellernuss (22.15 and $19.16 \mathrm{~mm}$ ), and the smallest in Cosford (15.58 and $13.68 \mathrm{~mm}$ ). According to research conducted by Ilić et al. (2017) slightly less similar or slightly smaller fruit dimensions were recorded in Istrian Long and Romische Zellernuss, while fruits were significantly larger compared to the Solar and Štampar research (2011). The largest kernel length was recorded in Istrian Long $(20.10 \mathrm{~mm})$ and the smallest in Romische Zellernuss $(13.89 \mathrm{~mm})$. The largest width and thickness of the nut was recorded in Romische Zelernuss (16.88 and $14.86 \mathrm{~mm})$ and the smallest in Cosford $(11.35$ and $10.32 \mathrm{~mm})$. The highest shell thickness was recorded in Istrian Long $(1.97 \mathrm{~mm})$ and the lowest in Cosford 
$(1.23 \mathrm{~mm})$. In relation to the research conducted by Ilić et al. (2017) much higher values for shell thickness were recorded.

Table 2. Average values of pomological characteristics of fruits of examined hazelnut cultivars after storage

\begin{tabular}{|l|c|c|c|c|}
\hline \multirow{2}{*}{\multicolumn{1}{|c|}{ After storage }} & \multicolumn{4}{c|}{ Cultivars } \\
\cline { 2 - 5 } & $\begin{array}{c}\text { Romische } \\
\text { Zellernuss }\end{array}$ & $\begin{array}{c}\text { Istrian } \\
\text { Long }\end{array}$ & $\begin{array}{c}\text { Istrian } \\
\text { Round }\end{array}$ & Cosford \\
\hline Measurements & Mean SE & Mean SE & Mean SE & Mean SE \\
\hline Nut weight (g) & $2.69 \pm 0.10$ & $4.01 \pm 0.10$ & $2.25 \pm 0.07$ & $1.97 \pm 0.04$ \\
\hline Kernel weight (g) & $1.22 \pm 0.07$ & $1.73 \pm 0.06$ & $1.03 \pm 0.02$ & $0.98 \pm 0.03$ \\
\hline Nut lenght (mm) & $18.60 \pm 0.27$ & $25.89 \pm 0.38$ & $19.13 \pm 0.17$ & $22.86 \pm 0.28$ \\
\hline Nut width (mm) & $22.11 \pm 0.16$ & $20.57 \pm 0.24$ & $18.10 \pm 0.21$ & $14.44 \pm 0.25$ \\
\hline Nut thickness (mm) & $19.48 \pm 0.22$ & $17.71 \pm 0.18$ & $16.45 \pm 0.23$ & $11.99 \pm 0.22$ \\
\hline Kernel lenght (mm) & $13.66 \pm 0.31$ & $19.98 \pm 0.16$ & $14.85 \pm 0.27$ & $16.89 \pm 0.38$ \\
\hline Kernel width (mm) & $16.75 \pm 0.22$ & $14.47 \pm 0.17$ & $14.46 \pm 0.22$ & $11.48 \pm 0.19$ \\
\hline Kernel thickness (mm) & $14.98 \pm 0.15$ & $12.07 \pm 0.21$ & $12.70 \pm 0.19$ & $9.75 \pm 0.20$ \\
\hline Shell thickness (mm) & $1.52 \pm 0.04$ & $1.79 \pm 0.05$ & $1.55 \pm 0.04$ & $1.18 \pm 0.02$ \\
\hline Presence od dual fruits & None & Presence & None & None \\
\hline Blank nuts (\%) & 16.66 & 3.33 & - & 9.99 \\
\hline Nut shape index & 1.11 & 0.73 & 0.90 & 0.57 \\
\hline Kernel percentage (\%) & 45.35 & 43.14 & 45.77 & 49.74 \\
\hline
\end{tabular}

The presence of dual nuts was recorded in Istrian Long and Istrian Round. The highest presence of blank nuts was recorded in Romische Zellernuss $(13.33 \%)$, and the lowest in Cosford $(6.66 \%)$. In relation to the research conducted by Miletić et al. (2002) it's recorded a slightly higher number of blank nuts in Romische Zellernuss and approximately the same number in Istrian Long. The highest nut shape index was recorded in Romische Zellernuss (1.07), and the lowest in Cosford (0.61). The values of the nut shape index are approximately equal to the values recorded by Solar and Stampar (2011), and significantly higher for Romische Zellernuss and approximately equal for Istrian Long compared to the research conducted by Miletić et al. (2002). The highest kernel percentage was recorded for Cosford $50.45 \%$, while the other three cultivars had an approximately uniform kernel percentage ranging from 45.73 for Istrian Long to $46.66 \%$ for Istrian Round. The values of kernel percentage in Romische Zellernuss and Istrian Long are significantly higher compared to the research conducted by Ilić et al. (2017), while compared to the research Solar and Štampar (2011) they are higher by approximately $3 \%$ for both cultivars.

The average values of pomological characteristics of the fruit in the examined hazelnut cultivars after storage are presented in Tab. 2 . 
Table 3. Sensory analyzes of fruits of examined hazelnut cultivars at harvest period

\begin{tabular}{|c|c|c|c|c|c|}
\hline \multirow{2}{*}{\multicolumn{2}{|c|}{ Harvest period }} & \multicolumn{4}{|c|}{ Cultivars } \\
\hline & & $\begin{array}{l}\text { Romische } \\
\text { Zellernuss }\end{array}$ & $\begin{array}{c}\text { Istrian } \\
\text { Long }\end{array}$ & Istrian Round & Cosford \\
\hline \multicolumn{6}{|c|}{ Sensory characteristics of nuts based on the descriptor Bioversity international } \\
\hline \multicolumn{2}{|l|}{ Shape } & Oblate & $\begin{array}{c}\text { Long } \\
\text { subcylndrical }\end{array}$ & Globular & $\begin{array}{c}\text { Long } \\
\text { subcylndrical }\end{array}$ \\
\hline \multirow{2}{*}{ Texture } & before roasting & $\begin{array}{l}\text { Medium } \\
\text { corky }\end{array}$ & Smooth & Lightly corky & Smooth \\
\hline & after roasting & $\begin{array}{c}\text { Medium } \\
\text { corky }\end{array}$ & Lightly corky & Lightly corky & Smooth \\
\hline \multirow{2}{*}{ Colour } & before roasting & Brown & Brown & Brown & Lightly brown \\
\hline & after roasting & Brown & Brown & Dark brown & Dark brown \\
\hline \multicolumn{6}{|c|}{ Sensory characteristics of kernels based on sensory tests performed with subjects } \\
\hline \multirow{2}{*}{ Taste* } & before roasting & $\begin{array}{c}\text { Very good } \\
(6 / 10)\end{array}$ & Very good $(7 / 10)$ & $\begin{array}{c}\text { Very good } \\
(6 / 10)\end{array}$ & $\begin{array}{c}\text { Very good } \\
(6 / 10)\end{array}$ \\
\hline & after roasting & $\begin{array}{c}\text { Satisfactory } \\
(7 / 10)\end{array}$ & Very good $(5 / 10)$ & $\begin{array}{c}\text { Very good } \\
(6 / 10)\end{array}$ & $\begin{array}{c}\text { Satisfactory } \\
(5 / 10)\end{array}$ \\
\hline \multirow{2}{*}{$\begin{array}{l}\text { Kernel } \\
\text { bitterness* }\end{array}$} & before roasting & Yes $(5 / 10)$ & No $(1 / 10)$ & No $(1 / 10)$ & No $(4 / 10)$ \\
\hline & after roasting & Yes $(5 / 10)$ & No $(4 / 10)$ & No $(2 / 10)$ & Yes $(6 / 10)$ \\
\hline \multirow{2}{*}{\begin{tabular}{|l|}
$\begin{array}{l}\text { Kernel } \\
\text { sweetness* }\end{array}$ \\
\end{tabular}} & before roasting & Yes $(5 / 10)$ & Yes $(6 / 10)$ & Yes $(8 / 10)$ & Yes $(5 / 10)$ \\
\hline & after roasting & No $(3 / 10)$ & Yes $(6 / 10)$ & Yes $(8 / 10)$ & No $(1 / 10)$ \\
\hline \multirow{2}{*}{ Hardness* } & before roasting & Yes $(6 / 10)$ & Yes $(9 / 10)$ & Yes $(9 / 10)$ & Yes $(6 / 10)$ \\
\hline & after roasting & Yes $(8 / 10)$ & Yes $(8 / 10)$ & Yes $(7 / 10)$ & Yes $(6 / 10)$ \\
\hline \multirow{2}{*}{ Crunchiness* } & before roasting & Yes $(6 / 10)$ & Yes $(5 / 10)$ & Yes $(5 / 10)$ & Yes $(7 / 10)$ \\
\hline & after roasting & Yes (10/10) & Yes $(9 / 10)$ & Yes $(8 / 10)$ & Yes (10/10) \\
\hline
\end{tabular}

* with the marked parameters the numerical assessment of the respondents from the total number is presented

The texture and color characteristics did not change much according to the treatment. In terms of taste, the cultivars showed quite the same taste before roasting according to the respondents while after roasting the taste quality was worse in the cultivars Romische Zellernuss and Cosford. Fruits with more pronounced bitterness of kernel were found in Romische Zellernuss during both observations, while bitterness was least pronounced in Istrian Round. In all cultivars there was an increase in bitterness of kernel after roasting. In terms of the sweet taste of the kernel, Istrian Round stood out in particular while the kernel of Cosford proved to be the worst. The fruits of all cultivars have, as expected, shown higher hardness and crunchiness after roasting.

Estimates of sensory characteristics of the fruit of the examined hazelnut cultivars after storage are presented in Tab. 4.

After five months of fruit storage, the largest changes were registered in fruit weight and thus in kernel weight, which affected the change in kernel percentage. Namely, in all observed cultivars was recorded shrinkage of fruits in the storage process, where is the largest magnitude of shrinkage of fruit and kernel recorded in Romische Zellernuss and the smallest one in Istrian Long. 
Markuszewski and Kopytowski (2015) also confirm the weight loss of nuts in the storage process. Cultivar Cosford maintained the best kernel percentage in the storage process, while the largest difference of this parameter of stored fruits in relation to the harvest was recorded in Istrian Long. By analyzing individual parameters of fruit dimensions does not record significant differences between fruits analyzed in different period. Different values of fruit dimensions as well as different presence of dual fruits and blank nuts at harvest and after storage can be related to different representative group of fruits sampled for two time periods of analysis.

Estimates of sensory characteristics of the fruit of the examined hazelnut cultivars at harvest period are presented in the Tab. 3 .

Table 4. Sensory analyzes of fruits of examined hazelnut cultivars after storage

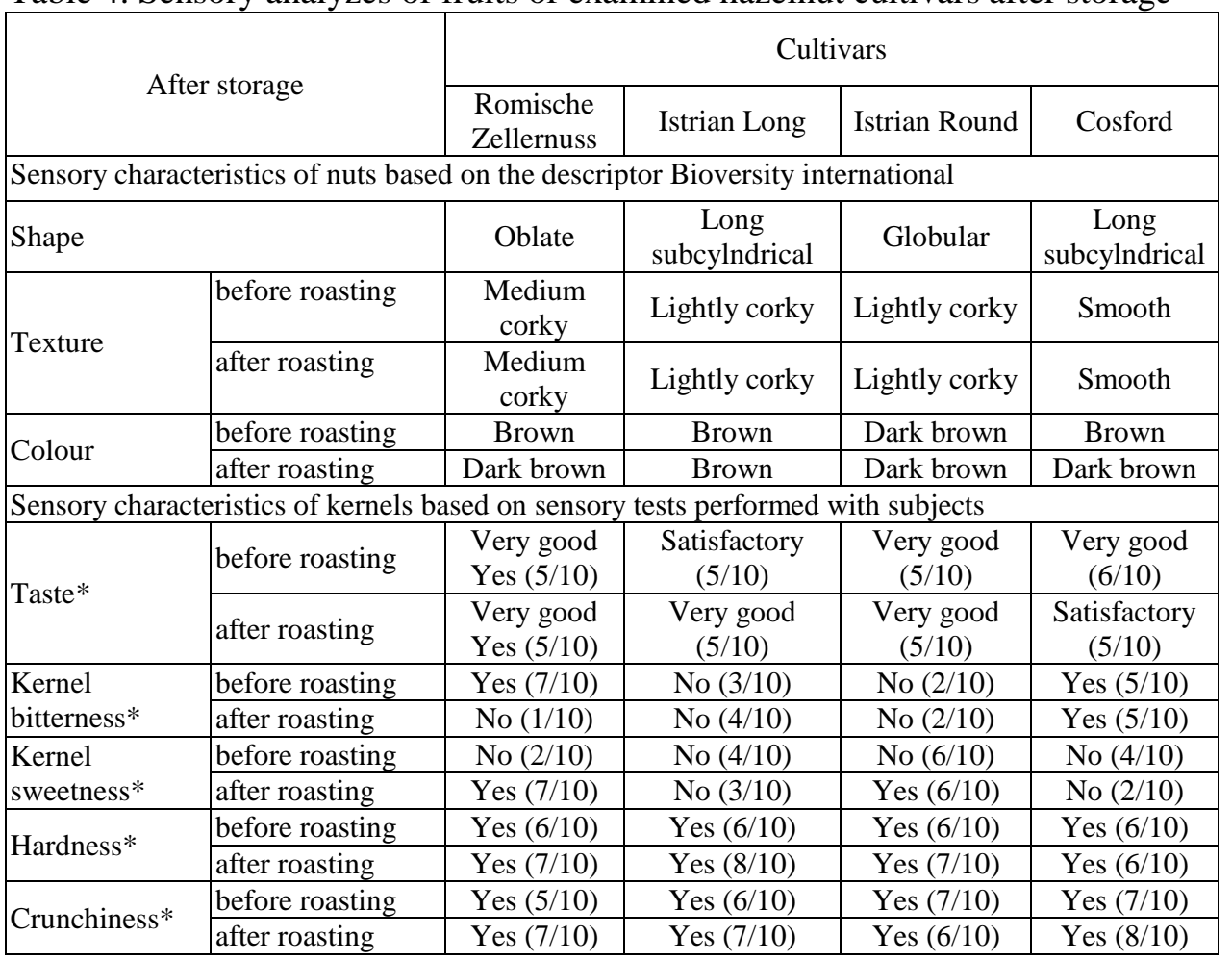

* with the marked parameters the numerical assessment of the respondents from the total number is presented

The data show that the stored fruits had a worse taste in the opinion of the respondents, especially Romische Zellernuss after roasting and Istrian Long cultivar before roasting. There was an increase in the bitterness of the fruit in storage process in all cultivars before roasting, while in Romische Zellernuss the bitterness is reduced after roasting. In the process of storage, there is a decrease in the sweetness of the fruits of the observed cultivars, except for Romische 
Zellernuss, which has a more intense sweetness after storage. The decrease in fruit hardness during storage was expressed in Istrian Long and Istrian Round, while the crunchiness of stored fruits was less present in the other two observed cultivars. The loss of taste and reduction of fruit crunchiness after storage of hazelnuts are also indicated by De Santis et al. (2009).

\section{CONCLUSIONS}

The results indicate different storage capacities of the examined hazelnut cultivars in the observed period in the chamber. Regardless of the fact that Istrian Long had the largest difference in kernel percentage between harvested fruits and stored fruits, this cultivar had the smallest magnitude of fruit shrinkage during storage, but also the largest fruits that maintained good hardness during storage. Cosford, in addition to the acceptable magnitude of fruit shrinkage, maintained good taste and crunchiness of the fruit in both treatments, before and after roasting. The fruits of Istrian Round had the largest sweetness and the least bitterness, which was least affected by the roasting process compared to other observed varieties. Considering that this is a preliminary research in the field of storage of this fruit species in the region of Republic of Srpska, the obtained results indicate the need for more detailed analyzes of storage systems and conditions for each cultivar separately and their impact on fruit quality. Also, the results of this research indicated the need for study the aroma and blanching (skinning of pelicule) of kernels before and after storage which are a very important features of the hazelnut kernel in the confectionery industry.

\section{REFERENCES}

Bioversity, FAO and CIHEAM (2008): Descriptors for hazelnut (Corylus avellana L.). Bioversity International, Rome, Italy; Food and Agriculture Organization of the United Nations, Rome, Italy; International Centre for Advanced Mediterranean Agronomic Studies, Zaragoza, Spain.

De Santis, D., Fardelli, A. and Mencarelli, F. (2009): Storage hazelnuts: effect on aromatic profile and sensory attributes. Acta Hortic., 845, 693-700.

Čmelik, Z., Mališević, E. (1996): Nature and quality of hazelnut fruit grown on pseudogley. Pomologia Croatica, 2, 3-11.

Ilić, P., Mićić, N., Đurić, G., Tojnko, S., Solar, A., Bosančič, B. (2017): Pomological description of hazel assortment (Corylus avellana L.) present in the plantations in Bosnia and Herzegovina. Agriculturae Conspectus Scientifucus, 82(4), 389-394.

Markuszewski, B., Kopytowski, J. (2015): Effects of storage conditions on the quality of unripe hazelnuts in the husk. Journal of Horticultural Research, 23(2), 59-67.

Miletić, R., Ogašanović, D., Mitrović, M., Petrović, R. (2002): Results of studying the most important pomological-technological properties of hazelnuts in eastern Serbia. J Jug Pomol., 36, 137-138.

Miljkovic, I. (2018): Hazelnut. Croatian fruit growing community, Zagreb.

Mitrović, M., Miletić, R., Lukić, M. (2009): Pomological-technological characteristics of introduced hazelnut varieties. Fruit Growing, 43, 53-56. 
Skender, A., Hadžiabulić, S., Aliman, J., Hasanbegović, J. (2019): Phenological and morphological traits of important hazelnut cultivars in North West Bosnia. Agroknowlegde Journal, 20(4), 197-206.

Solar, A., Stampar, F. (2011): Characterisation of selected hazelnut cultivars: phenology. growing and yielding capacity market quality and nutraceutical value. J. Sci. Food Agric., 91, 1205-1212.

Turan, A. (2018): Effect of drying methods on fatty acids profile and oil oxidation of hazelnut oil during storage. European Food Research and Technology, 244, 21812190.

Zavišić, N., Davidovic Gidas, J., Zeljkovic, S., Đurić, G. (2020): Production of fruit planting material in the Republic of Srpska in the period 2009-2019. IX International Symposium on Agricultural Sciences AgroRes, 88.

Croatian Bureau of statiscs (available at https://www.dzs.hr/default_e.htm)

Statistical office of the Republic of Serbia (available at https://www.stat.gov.rs/enUS/oblasti/poljoprivreda-sumarstvo-i-ribarstvo/visegodisnjizasadi) 